\title{
Campomanesia genus - a literature review of nonvolatile secondary metabolites, phytochemistry, popular use, biological activities, and toxicology
}

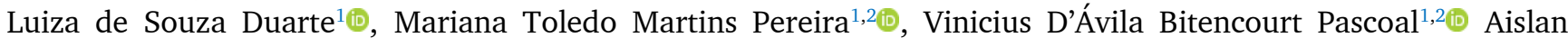
Cristina Rheder Fagundes Pascoal ${ }^{1,2+}$

1. Universidade Federal Fluminense, Instituto de Saúde de Nova Friburgo, Rua Dr. Sílvio Henrique Braune, 22 Nova Friburgo, Rio de Janeiro, Brazil

2. Universidade Federal Fluminense, Instituto de Biologia, Programa de Pós-Graduação em Ciências e Biotecnologia, Alameda Barros Terra, Niterói, Rio de Janeiro, Brazil

${ }^{+}$Corresponding author: Aislan Cristina Rheder Fagundes Pascoal, Phone: +55 22 2528-7663, Email address: aislanfagundes@id.uff.br

\section{ARTICLE INFO}

Article history:

Received: September 2, 2019

Accepted: March 18, 2020

Published: April 1, 2020
Keywords:

1. Myrtaceae

2. natural products

3. biological activities

4. pharmacological potential

5. popular use

\begin{abstract}
The genus Campomanesia belongs to the Myrtaceae family and has about 30 species. It is characterized by citrus-flavored fruits. Several articles describe the extensive use of its fruit, such as in the food industry, however, other parts of the plants are also used for food or pharmacological purposes such as the leaves, flowers, seeds, and roots. Analyzing works published on the genus in the period 2005-2019, we observed that the classes of main flavonoid compounds present are anthocyanins, chalcones, coumarins, tannins, and saponins. Species of this genus are also

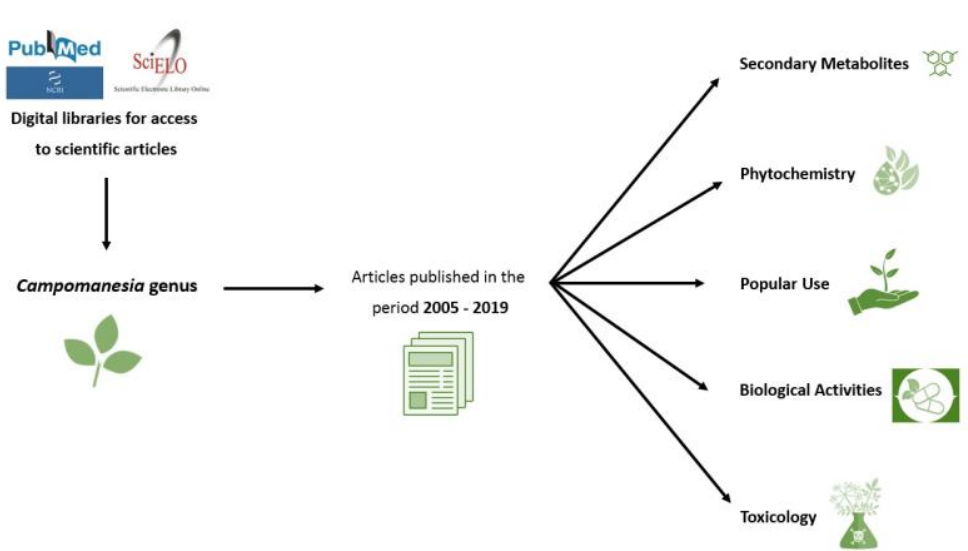
used as a medicine in the treatment of wounds, toothaches, fractures, and bruises. Therapeutic activities have also been detected for Campomanesia, such as antimicrobial, antiulcerogenic, antiprotozoal, anti-inflammatory, and antidiarrheal activity, antiproliferative and antioxidant potential, antiplatelet, antithrombotic, and fibrinolytic activities, as well as hypotensive effects. There are a small number of works demonstrating the low toxic potential of plant extracts. Thus, the Campomanesia genus presents pharmacological potential to be explored.
\end{abstract}

\section{CONTENTS}

\section{Introduction}

2. Secondary metabolites and phytochemistry

3. Popular use

4. Biological activities

5. Toxicology

6. Conclusion and future perspectives

7. Acknowledgments

8. References

\section{Introduction}

Plants can be used as sources of alternative substances, including therapeutic resources for human medicines ${ }^{1}$. Mesopotamian documents, dated $2600 \mathrm{BC}$, show the use of more than 1,000 production plants, including those that are now untreated, colds, parasitic, and inflammation ${ }^{2}$. When we analyze the medicines released between 1981 and 2014, 4\% are produced from natural

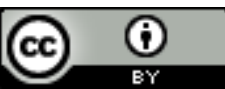


products, and $27 \%$ are synthetic compounds. However, considering the origin of the other products, $59.1 \%$ are semi-synthetic molecules, synthetic drugs with pharmacophoric groups, based on natural product structures, mimicking natural or botanical products ${ }^{3}$.

The use of medicinal plants as an alternative or additional therapeutic resources has increased significantly ${ }^{4}$. Although synthetic drugs are usually the first choice of treatment for many diseases, these chemical drugs sometimes have undesirable effects and, consequently, the acceptance of alternative medicines has increased substantially ${ }^{5}$. Also, in some pathologies, resistance is developing to the drugs already used in treatment. These data demonstrate the importance of natural products in drug research, and the development of new medicines, justifying work in this area. The Scielo and PubMed databases were searched, during the period 20052019, and the keywords used were: Campomanesia, Myrtaceae, "Campomanesia and biological activities," "Campomanesia and popular use," "Campomanesia and toxicology."

The Myrtaceae family comprises 175 genera and 5,970 species, native to all continents of the southern hemisphere ${ }^{6}$. They are divided into shrubs and trees with sebaceous glands in the leaves, lower or semi-inferior ovaries, flowers, usually, with numerous stamens, internal phloem, and traces of xylem vessels ${ }^{7,8}$. The genus Campomanesia belongs to the Myrtaceae family and has about 30 species?. This genus is characterized by its citrus-flavored fruits ${ }^{10}$. However, although several articles describe the extensive use of the fruit, such as in the food industry, other parts of the plants are also used for food or pharmacological purposes, such as leaves, flowers, seeds, and roots.

The species include: $C$. xanthocarpa, $C$. adamantium, C. corimbosa, C. cambessedean, $C$. pubescens, C. guazumifolia, C. reitziana, and $C$. lineatifolia, among others.

\section{Secondary metabolites and phytochemistry}

A striking feature of the genus Campomanesia is the presence of the high content of phenolic compounds, mainly in Campomanesia adamantium. Analyzing works published in the period 2005-2019 for the genus, we observed that the main classes of flavonoid compounds present are anthocyanins, chalcones, coumarins, tannins, and saponins. These compounds have in common the biosynthetic pathway derived from phenylpropanoids that contribute to all aspects of plant responses to biotic and abiotic stimuli ${ }^{11}$.

However, changes occur in the formation, concentration, and type of secondary metabolites in the various species, which may be influenced by the environmental stress, climate, and soil of each region. For example, fruits of Campomanesia xanthocarpa contain a high concentration of phenolic compounds, including chlorogenic acid and ascorbic acid ${ }^{12}$ and the leaves contain a large number of saponins, tannins, and terpenes, besides the consistent presence of flavonoids and phenolic compounds, such as gallic acid, quercetin, and chlorogenic $\operatorname{acid}^{13,14}$.

Campomanesia adamantium is one of the most commonly studied species. It has shown significant therapeutic potential, in addition to the presence of phenolic compounds such as gallic acid, catechins, ellagic acid, and flavonoids ${ }^{15,16}$.

Fruits of Campomanesia pubescens, when ripe, have a high content of vitamin $\mathrm{C}$ and phenolic compounds $^{17}$, among them, flavanones and chalcones ${ }^{18,19}$.

Few studies describe both the biological activities and compounds of Campomanesia guazumifolia. However, a survey by Catelan et al. ${ }^{20}$ identified the presence of glycosylated flavonoids: quercetin pentose, quercetin deoxyhexoside, myricetin deoxyhexoside, and quinic acid. The fruits of the $C$. reitziana species contain dimethyl cardamonine as their main active compound $^{21}$

Phytochemical studies with the $C$. lineatifolia species revealed the presence of flavonoids, tannins, catechin, quercitrin, and champanones $\mathrm{A}$, $\mathrm{B}$, and $\mathrm{C}^{22}$. A survey by Osorio et al. showed that the beta-tricetones compound contributes to the fruity odor ${ }^{23}$.

Campomanesia leaves are rich in volatile oils, which were reviewed by Stefanello et al. in 2011, who described geraniol, $\alpha$-pinene, limonene, linalool, spathulenol, and caryophyllene ${ }^{24}$. The essential oil from $C$. guaviroba was analyzed, and sixteen compounds were identified, of which the largest constituent was myrtenal ${ }^{25}$.

\section{Popular use}

The Myrtaceae family presents a wide variety of fruits, which are consumed throughout the 
Brazilian territory and present characteristics of a considerable amount of acidity through ascorbic acid, minerals, fibers, and monoterpene hydrocarbons. Fruits are used to make liqueurs, juices, and sweets. However, the population uses other parts such as the leaves, seeds, and roots in the form of powders, gums, teas, juices, oils, or different types associated with medicinal use ${ }^{10,26}$. Native species from the Midwest region, such as Campomanesia, are used by indigenous peoples as food since they represent a source of vitamins and minerals ${ }^{27}$. However, species of this genus are also used as a medicine in the treatment of wounds, toothaches, fractures, and bruises ${ }^{28}$.

From the advances in research directed to natural products, the use of medicinal plants has significantly increased, to provide alternative or additional forms of treatments used in the daily life of the population. C. xanthocarpa is an example of this species which is associated with popular and traditional use, as it demonstrates extensive medicinal use: fruit peel infusions for the treatment of productive cough and dysentery, leaf tea for reducing cholesterol and fighting urinary and uterine infections, and the peel can be used to treat cystitis, diarrhea, and hemorrhoids ${ }^{13,28}$. C. pubescens is used by the population of Mato Grosso (Brazilian State) as food (jelly, juices, and liqueurs) and also as a medicinal plant due to its purifying, antidiarrheal, and cholesterol-lowering action ${ }^{29,30}$. Infusions of C. velutina leaves and branches are popularly used to treat diarrhea and intestinal cramps ${ }^{31}$.

\section{Biological activities}

One of the most commonly studied activities is in vitro antioxidant activity. DPPH is the most widely used method, probably because these are quick and cheap chemical tests ${ }^{32}$. This activity is related to the concentration of phenolic compounds present in samples. Antimicrobial activities against anti-inf, fungi, and protozoa are also widely studied ${ }^{22,33,34}$.

The biological activities described are listed in Tab. 1, including anti-inflammatory, cytotoxic, antinociceptive, and protective activities of the gastric mucosa. These activities, in most cases, are related to flavonoid activities, which are effective in some cases ${ }^{35}$.

C. xanthocarpa has been studied to confirm its popular use in treatment for hypercholesterolemic patients; this species was able to reduce blood levels of $\mathrm{TC}$ and $\mathrm{LDL}^{13}$. In addition to this effect, it has been shown that this species has important therapeutic activities such as antimicrobial ${ }^{36}$, antiulcerogenic $^{37}$, antiprotozoal ${ }^{34}$, antiinflammatory $^{38}$, and antidiarrheal ${ }^{39}$ as well as antioxidant potential $^{40}, \quad$ antiplatelet, antithrombotic, and fibrinolytic activities ${ }^{41,42}$, and, more recently, hypotensive effects ${ }^{14}$.

Campomanesia adamantium has the characteristic of being a small tree that produces edible fruits with beneficial effects on health, presenting activities such as antimicrobial ${ }^{18,27,33,43}$, antidiarrheal ${ }^{44}$, and antiproliferative $\mathrm{e}^{45,46}$. In addition, its leaves and roots have antiinflammatory and antinociceptive activities ${ }^{47}$.

In the studies conducted with $C$. guazumifolia, the antioxidant activity, antimicrobial activity, and anti-inflammatory potential with low toxicity of leaf infusions of this species were evidenced ${ }^{20}$. Few biological activities are described for $C$. reitziana and $C$. lineatifolia. $C$. reitziana showed antinociceptive and gastroprotective potential, and C. lineatifolia demonstrated anti-inflammatory and gastroprotective effects ${ }^{21,48,49}$.

\section{Toxicology}

Currently, plants are used as food, nutraceuticals, phytonutrients, medicinal plants, and herbal medicines, thus representing alternative therapies to existing treatments for various pathologies ${ }^{28,50}$. Despite the widespread use of plants as medicine and functional food, there is often no scientific evidence to support their pharmacological properties and toxic potential $^{51,52}$. It is estimated that only threequarters of the currently marketed natural products of plant origin have the safety information that enables their proper use $^{53}$. Regarding Campomanesia, this scenario is no different. Although these species are widely used as food and medicine in folk medicine, studies on the toxicology of many species are still scarce ${ }^{54}$.

A study on the acute and subacute toxicity of ethanolic extract of $C$. guazumifolia leaves, where adult and female rats received the extract orally at different concentrations for 14 and 28 days respectively, showed that the doses used did not produce significant physiological or pathological changes, or mortality, indicating that the LD50 is greater than $2000 \mathrm{mg} \mathrm{kg}^{1}{ }^{154}$. Leaf infusion of the same species was shown to have low toxicity in in vivo models of acute and subacute toxicity, with 
no observed clinical signs or changes in hematological, biochemical, or histological parameters, suggesting that the LD50 is above $5000 \mathrm{mg} \mathrm{kg}^{-120}$.

A similar study of acute and sub-chronic toxicity using the aqueous extract of $C$. velutina leaves and branches demonstrated different changes in male and female Swiss mice. The extracts at doses of 600 and $1200 \mathrm{mg} \mathrm{kg}^{-1}$ showed signs of toxicity such as diarrhea, anemia, changes in the kidneys, brain, and heart, suggesting that the safest dose of the extracts is $300 \mathrm{mg} \mathrm{kg}^{-1}{ }^{31}$. The ethanolic extract of $C$. pubescens leaves demonstrated cytotoxic and genotoxic effects through Allium strain bioassay, toxic effects were observed in the dividing cell and increased chromosomal alterations ${ }^{20}$. In vivo studies with Wistar and Drosophila melanogaster rats showed that the ethanolic extract obtained from fruits of C. pubescens under the experimental conditions used did not demonstrate significant genotoxic or clastogenic effects, indicating that fruit consumption is safe $\mathrm{e}^{54}$.

The aqueous extract and essential oil of $C$. xanthocarpa leaves were also evaluated using the Allium strain test, allowing the observation of a genotoxic effect of the samples: mitotic index reduction and chromosomal mutations ${ }^{55}$. The extract of the leaves of this same species, when submitted to acute toxicity test in vivo, showed no signs of toxicity ${ }^{38}$. Hydroalcoholic extract from $C$. adamantium fruits, when subjected to acute and subacute toxicity tests in Wistar rats, proved to be safe, as no clinical signs of toxicity were observed $^{56}$.

Preclinical toxicity studies of herbal medicines are recommended by international regulatory agencies. In Brazil, the National Health Surveillance Agency (ANVISA) is the body responsible for regulating these products and includes, among its various resolutions, a specific one for toxicity tests, aiming to ensure and evaluate the safety and quality of herbal medicines before they are used by the population $^{57}$. However, toxicity tests with species of the genus Campomanesia are still scarce, requiring further studies in this area.

\section{Conclusion and future perspectives}

Several articles published in recent years demonstrate the importance of the genus Campomanesia, not only as food but also, mainly, for its pharmacological potential. In this sense, studies claim that different parts of the plants of this genus present promising results for various biological activities, ranging from antioxidant activity to antiproliferative activity, for example. The secondary metabolism of plants is responsible for the production of compounds that have these biological activities. In the case of the Campomanesia genus, phenolic acids and other groups of compounds such as flavonoids, anthocyanins, and tannins stand out. Through these studies, the potential of these species to treat different diseases becomes evident. However, for this genus to be used commercially, a lot of work is needed to produce a finished product. For herbal medicine, studies of the major compounds present, markers, and quantifications of these compounds should be performed. Besides, for the development of allopathic medications, active compounds must be isolated, and the structure identified, as well as analysis of the biological activities. Toxicity tests and possible mechanisms of action are also required. Given this, there is a vast territory to be explored, represented by the genus Campomanesia. 
Table 1. Description of the studied species, parts, biological activity found, and identified compounds from the Campomanesia genus.

\begin{tabular}{|c|c|c|c|c|}
\hline Genus & $\begin{array}{l}\text { Part of the plant } \\
\text { and extract }\end{array}$ & Biological Activities & Compounds & Reference \\
\hline C. adamantium & $\begin{array}{l}\text { The ethanolic } \\
\text { crude extract of } \\
\text { leaves and ethyl } \\
\text { acetate and butanol } \\
\text { fractions }\end{array}$ & Antioxidant activity & Isoquercitrin and quercetin & {$[58]$} \\
\hline C. adamantium & $\begin{array}{l}\text { Ethyl acetate and } \\
\text { aqueous extracts of } \\
\text { leaves }\end{array}$ & $\begin{array}{l}\text { Antinociceptive and anti- } \\
\text { inflammatory activities }\end{array}$ & Myricitrin, myricetin, and quercetin & [47] \\
\hline C. adamantium & $\begin{array}{l}\text { Fruit and leaf } \\
\text { extracts }\end{array}$ & $\begin{array}{l}\text { Antiproliferative activity in } \\
\text { the PC- } 3 \text { cells }\end{array}$ & Cardamonin & [45] \\
\hline C. adamantium & $\begin{array}{l}\text { Hydroalcoholic } \\
\text { extract of fruit } \\
\text { peels }\end{array}$ & $\begin{array}{l}\text { Anti-inflammatory, } \\
\text { antihyperalgesic and } \\
\text { antidepressant activities }\end{array}$ & $\begin{array}{l}\text { Quercetin, myricetin, 5,7-dihydroxy-6 } \\
\text { methylflavanone, 5,7 dihydroxy-8 } \\
\text { methylflavanone and } 2 \text { '4'-dihydroxy6'- } \\
\text { methoxycalcon and in the ethyl acetate } \\
\text { fraction of 7-hydroxy-5-methoxy-6 - } \\
\text { methylflavanone, 5,7-dihydroxy-6,8- } \\
\text { dimethylflavanone, and 2', 4'-dihydroxy } \\
\text { 3',5'-dimethyl-6'-methoxyicalcone }\end{array}$ & [56] \\
\hline C. adamantium & $\begin{array}{l}\text { Hydroalcoholic } \\
\text { fruit extract }\end{array}$ & $\begin{array}{l}\text { Hepatoprotective activity in } \\
\text { vitro }\end{array}$ & Presence of flavonoids & [48] \\
\hline C. adamantium & $\begin{array}{l}\text { Ethanolic extracts } \\
\text { of leaves, bark, and } \\
\text { seeds }\end{array}$ & Antifungal Potential & - & [59] \\
\hline C. adamantium & $\begin{array}{l}\text { Aqueous root } \\
\text { extract }\end{array}$ & $\begin{array}{l}\text { Antioxidant and } \\
\text { antihyperlipidemic }\end{array}$ & Gallic acid and ellagic acid & {$[60]$} \\
\hline C. adamantium & Peel Extract & $\begin{array}{l}\text { Antidiarrheal, cytotoxic, and } \\
\text { anti-inflammatory activities }\end{array}$ & Phenolic compounds & [44] \\
\hline C. adamantium & $\begin{array}{l}\text { Aqueous extract of } \\
\text { leaves and roots }\end{array}$ & Antileukemic activity & $\begin{array}{l}\text { di-hexoside/quinic acid, ellagic acid O- } \\
\text { pentoside, ellagic acid, O-methyl ellagic } \\
\text { acid O-hexoside, ellagic acid O- } \\
\text { deoxyhexoside, and O-methyl ellagic acid } \\
\text { sulfate, gallic acid, ellagic acid O-hexoside, } \\
\text { O-methyl ellagic acid O-deoxyhexoside, and } \\
\text { O-dimethyl ellagic acid sulfate }\end{array}$ & {$[61]$} \\
\hline C. adamantium & $\begin{array}{l}\text { Dichloromethane } \\
\text { extracts from pulp } \\
\text { and fruit peel }\end{array}$ & Antiproliferative activity & $\begin{array}{l}\text { 7-hydroxy-5-methoxy6-C-methylflavanone, } \\
\text { 5,7-dihydroxy6-C-methylflavanone, 5,7- } \\
\text { dimethoxy6-C-methylflavanone, 5,7- } \\
\text { dihydroxy-6, 8-C-methylflavanone, 4',6'- } \\
\text { dihydroxy-30-methyl20-methoxy-chalcone, } \\
\text { Champanone C, 4',6'-dihydroxy-30, 5'- } \\
\text { dimethyl-2' -methoxy -chalcone and } \\
\text { Champanone D }\end{array}$ & [46] \\
\hline C. adamantium & $\begin{array}{l}\text { Methanolic bark } \\
\text { extract }\end{array}$ & Potential antiplatelet effect & $\begin{array}{l}\text { Phenolic Compounds, Total Flavonoids, } \\
\text { Condensed Tannins }\end{array}$ & {$[62]$} \\
\hline C. guazumifolia & $\begin{array}{l}\text { Aqueous extract of } \\
\text { the leaves }\end{array}$ & $\begin{array}{l}\text { Anti-inflammatory potential } \\
\text { with low toxicity }\end{array}$ & $\begin{array}{l}\text { Quercetin pentose, quercetin deoxyhexoside, } \\
\text { myricetin deoxyhexoside, and quinic acid. }\end{array}$ & {$[20]$} \\
\hline C. lineatifolia & $\begin{array}{l}\text { Methanolic seed } \\
\text { extract }\end{array}$ & Antimicrobian activity & $\begin{array}{l}\text { Champanone A, Champanone B, and } \\
\text { Champanone C. }\end{array}$ & [22] \\
\hline C. pubescens & $\begin{array}{l}\text { Ethanolic Fruit } \\
\text { Extract }\end{array}$ & $\begin{array}{l}\text { Anxiolytic and } \\
\text { antidepressant effects }\end{array}$ & $\begin{array}{l}\text { 1,2-hydroxy3'-methyl-4', 6'- } \\
\text { dimethoxychalcon and 2, 7-hydroxy5- } \\
\text { methoxy-6-methylflavanone, 3, 5-hydroxy- } \\
\text { 7-methoxy-8-methylflavanone; 4, 2', 4'- } \\
\text { dihydroxy-3', 5'-dimethyl6'- } \\
\text { methoxychalcone; and 5, 2', 4'-dihydroxy- } \\
\text { 5'-methyl-6'-methoxychalcona }\end{array}$ & [63] \\
\hline
\end{tabular}




\begin{tabular}{|c|c|c|c|c|}
\hline \multicolumn{5}{|c|}{ continuation of Table 1.} \\
\hline C. pubescens & $\begin{array}{l}\text { Fresh fruit } \\
\text { ethanolic extract }\end{array}$ & $\begin{array}{l}\text { Low acute and subchronic } \\
\text { toxicity }\end{array}$ & $\begin{array}{l}\text { 2-hydroxy3'-methyl-4', 6'- } \\
\text { dimethoxychalcon; 7-hydroxy-5-methoxy-6- } \\
\text { methylflavanone; 5-hydroxy-7-ethoxy-8- } \\
\text { methylflavanone; 2', 4'-dihydroxy3', 5'- } \\
\text { dimethyl-6'-methoxychalcone and 2', 4'- } \\
\text { dihydroxy-5'-methyl-6'-methoxychalcone. }\end{array}$ & [54] \\
\hline C. pubescens & $\begin{array}{l}\text { Ethanolic leaf } \\
\text { extract }\end{array}$ & $\begin{array}{l}\text { Antioxidant activity and } \\
\text { suggested cytotoxic and } \\
\text { genotoxic effects }\end{array}$ & $\begin{array}{l}\text { 7-hydroxy-6-methyl-5-methoxyflavanone, } \\
\text { 5,7-dihydroxy-6-methylflavanone, 5,7- } \\
\text { dihydroxy-8-methylflavanone, } 2^{\prime}, 4^{\prime}- \\
\text { dihydroxy-6'-methoxychalcone, 5,7- } \\
\text { dihydroxy-6,8- dimethylflavanone, 2',4'- } \\
\text { dihydroxy-5'-methyl-6'-methoxychalcone } \\
\text { and 2',4'-dihydroxy-3',5'-dimethyl-6'- } \\
\text { methoxychalcone }\end{array}$ & [64] \\
\hline C. pubescens & $\begin{array}{l}\text { Ethanol extract of } \\
\text { fruit pulp }\end{array}$ & $\begin{array}{l}\text { Low toxicity without } \\
\text { genotoxic or clastogenic } \\
\text { effects. }\end{array}$ & High levels of flavonoids & [65] \\
\hline C. velutina & $\begin{array}{l}\text { Aqueous extract of } \\
\text { leaves and } \\
\text { branches }\end{array}$ & $\begin{array}{l}\text { Acute and subchronic } \\
\text { toxicity. }\end{array}$ & $\begin{array}{l}\text { Presence of phenolic compounds including } \\
\text { flavonoids and tannins }\end{array}$ & [31] \\
\hline C. xanthocarpa & $\begin{array}{l}\text { Aqueous extract of } \\
\text { the leaves }\end{array}$ & $\begin{array}{l}\text { Reduction in weight gain } \\
\text { and blood glucose in } \\
\text { animals }\end{array}$ & - & [66] \\
\hline C. xanthocarpa & $\begin{array}{l}\text { Hydroalcoholic } \\
\text { extract of the } \\
\text { leaves }\end{array}$ & $\begin{array}{l}\text { Antiulcerogenic action and } \\
\text { showed no acute toxic } \\
\text { effects }\end{array}$ & $\begin{array}{l}\text { Presence of flavonoids, saponins, and } \\
\text { tannins }\end{array}$ & [37] \\
\hline C. xanthocarpa & $\begin{array}{l}\text { Aqueous extract of } \\
\text { the leaves }\end{array}$ & $\begin{array}{l}\text { Antiplatelet, antithrombotic, } \\
\text { and fibrinolytic activity in } \\
\text { mice and also in human } \\
\text { blood and mice obtained } \\
\text { antithrombotic activity. }\end{array}$ & $\begin{array}{l}\text { Presence of saponins, tannins, and terpenes } \\
\text { and a small presence of flavonoids }\end{array}$ & [41] \\
\hline C. xanthocarpa & Fruits & Antioxidant activities & Phenolic compounds and ascorbic acid. & [40] \\
\hline C. xanthocarpa & Aqueous extract & $\begin{array}{l}\text { Anti-Trichomonas vaginalis } \\
\text { activity }\end{array}$ & 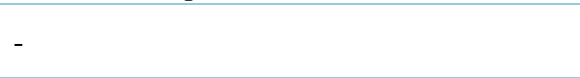 & [34] \\
\hline C. xanthocarpa & $\begin{array}{l}\text { Extract of the } \\
\text { leaves }\end{array}$ & $\begin{array}{l}\text { Protective effect on the } \\
\text { endothelium }\end{array}$ & - & [67] \\
\hline C. xanthocarpa & $\begin{array}{l}\text { Aqueous extract of } \\
\text { fresh plant }\end{array}$ & $\begin{array}{l}\text { Inhibit biofilm formation } \\
\text { and bacterial growth. }\end{array}$ & - & [68] \\
\hline C. xanthocarpa & $\begin{array}{l}\text { Hydroalcoholic } \\
\text { leaf extract }\end{array}$ & $\begin{array}{l}\text { Anti-Inflammatory Activity } \\
\text { without toxicity }\end{array}$ & $\begin{array}{l}2 \text { ', 6'-dihydroxy-3'-methyl-4'- } \\
\text { methoxychalcone and 2', 4'-dihydroxy-3 ', } \\
\text { 5'-dimethyl-6'-methoxychalcone }\end{array}$ & [38] \\
\hline C. xanthocarpa & Leaf extract & Antiplatelet Activity & - & [42] \\
\hline C. xanthocarpa & $\begin{array}{l}\text { Aqueous extract of } \\
\text { the leaves }\end{array}$ & Hypotensive effect & $\begin{array}{l}\text { Presence of gallic acid, chlorogenic aci, and } \\
\text { quercetin, theobromine }\end{array}$ & [14] \\
\hline C. xanthocarpa & Fruits & Antioxidant activity & $\begin{array}{l}\text { Lutein, Zeaxanthin, } \beta \text {-cryptoxanthin, } \alpha \text { - } \\
\text { carotene, } \beta \text {-carotene, Lycopene, Thiamine, } \\
\text { Riboflavin, Pantothenic Acid, Pyridoxine, } \\
\text { Biotin, Vitamin C, Vitamin A }\end{array}$ & [69] \\
\hline C. xanthocarpa & $\begin{array}{l}\text { Aqueous extract of } \\
\text { the leaves }\end{array}$ & $\begin{array}{l}\text { Antioxidant activity, } \\
\text { protective effect against } \\
\text { DNA in blood cells and } \\
\text { reduced LPO levels and } \\
\text { increased SOD activity in } \\
\text { kidney }\end{array}$ & $\begin{array}{l}\text { Presence of quercetin, rutin, and ellagic, } \\
\text { rosmarinic, caffeic, gallic, } \\
\text { and chlorogenic acids in the extract. }\end{array}$ & [70] \\
\hline
\end{tabular}




\section{Acknowledgments}

This study was financed in part by the Coordenação de Aperfeiçoamento de Pessoal de Nível Superior - Brasil (CAPES) - Finance Code 001.

\section{References}

[1] Brandão, H. N., David, J. P., Couto, R. D., Nascimento, J. A. P., David, J. M., Química e Farmacologia de Quimioterápicos Antineoplásicos Derivados de Plantas, Química Nova 33 (6) (2010) 1359-1369. 40422010000600026 .

[2] Borchardt, J. K., The Beginnings of Drug Therapy: Ancient Mesopotamian Medicine, Drug News \&

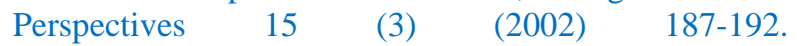
https://doi.org/10.1358/dnp.2002.15.3.840015.

[3] Newman, D. J., Cragg, G. M., Natural Products as Sources of New Drugs from 1981 to 2014, Journal of Natural Products 79 (3) (2016) 629-661. https://doi.org/10.1021/acs.jnatprod.5b01055.

[4] Ríos, J. L., Recio, M. C., Medicinal plants and antimicrobial activity, Journal of Ethnopharmacology $100 \quad(1-2) \quad$ (2005) 80-84. https://doi.org/10.1016/j.jep.2005.04.025.

[5] Sahib, N. G., Saari, N., Ismail, A., Khatib, A., Mahomoodally, F., Hamid, A. A., Plants' Metabolites as Potential Antiobesity Agents, The Scientific World Journal $2012 \quad$ (436039) (2012) 1-8. https://doi.org/10.1100/2012/436039.

[6] The Plant List., Myrtaceae, The Plant List: A working list of all plant species (2018). http://www.theplantlist.org/1.1/browse/A/Myrtaceae.

[7] Wilson, P. G., O'Brien, M. M., Gadek, P. A., Quinn, C. J., Myrtaceae revisited: A reassessment of infrafamilial groups, American Journal of Botany 88 (11) 2013-2025. https://doi.org/10.2307/3558428.

[8] Conti, E., Litt, A., Wilson, P. G., Graham, S. A., Briggs, B. G., Johnson, L. A. S., Sytsma, K. J., Interfamilial relationships in Myrtales: molecular phylogeny and patterns of morphological evolution, Systematic Botany 22 (4) (1997) 629-647. https://doi.org/10.2307/2419432.

[9] Landrum, L. R., Campomanesia, Pimenta, Blepharocalyx, Legrandia, Acca, Myrrhinium e Luma (Myrtaceae), In: Flora Neotropica, The New York
Botanical Garden: New York, United States of America, 1986, ch2.

[10] Silva, C. A. de A., Fonseca, G. G., Brazilian savannah fruits: Characteristics, properties, and potential applications, Food Science and

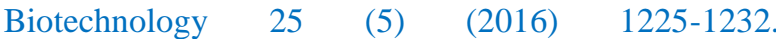
https://doi.org/10.1007/s10068-016-0195-3.

[11] Vogt, T., Phenylpropanoid Biosynthesis,

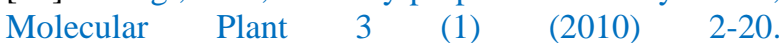
https://doi.org/10.1093/mp/ssp106.

[12] Furukawa, S., Fujita, T., Shimabukuro, M., Iwaki, M., Yamada, Y., Nakajima, Y., Nakayama, O., Makishima, M., Matsuda, M., Shimomura, I., Increased oxidative stress in obesity and its impact on metabolic syndrome, The Journal of Clinical Investigation 114 (12) (2017) 1752-1761. https://doi.org/10.1172/JCI21625.

[13] Klafke, J. Z., Silva, M. A. da, Panigas, T. F., Belli, K. C., Oliveira, M. F. de, Barichello, M. M., Rigo, F. K., Rossato, M. F., Santos, A. R. S. dos, Pizzolatti, M. G., Ferreira, J., Viecili, P. R. N., Effects of Campomanesia xanthocarpa on biochemical, hematological and oxidative stress parameters in hypercholesterolemic patients, Journal of $\begin{array}{lllll}\text { Ethnopharmacology } & 127 & \text { (2-3) } & \text { (2010) } & \text { 299-305. }\end{array}$ https://doi.org/10.1016/j.jep.2009.11.004.

[14] Sant'Anna, L. S., Merlugo, L., Ehle, C. S., Limberger, J., Fernandes, M. B., Santos, M. C., Mendez, A. S. L., Paula, F. R., Moreira, C. M., Chemical composition and hypotensive effect of Campomanesia xanthocarpa, Evidence-Based Complementary and Alternative Medicine 2017 (1591762) (2017) 1-11. https://doi.org/10.1155/2017/1591762.

[15] Espindola, P., da Rocha, P., Carollo, C., Schmitz, W., Pereira, Z., Vieira, M., dos Santos, E., Souza, K., Antioxidant and antihyperlipidemic effects of Campomanesia adamantium O. Berg Root, Oxidative Medicine and Cellular Longevity 2016 (7910340) (2016) 1-8. https://doi.org/10.1155/2016/7910340.

[16] Alves, A. M., Dias, T., Hassimotto, N. M. A., Naves, M. M. V., Ascorbic acid and phenolic contents, antioxidant capacity and flavonoids composition of Brazilian Savannah native fruits, Food Science and

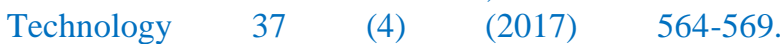
https://doi.org/10.1590/1678-457x.26716.

[17] Duarte, W. F., Dias, D. R., Pereira, G. V. de M., Garvásio, I. M., Schwan, R. F., Indigenous and inoculated yeast fermentation of gabiroba (Campomanesia pubescens) pulp for fruit wine 
production, Journal of Industrial Microbiology \&

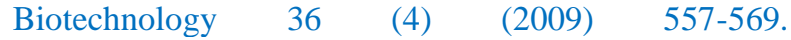
https://doi.org/10.1007/s10295-009-0526-y.

[18] Cardoso, C. A. L., Salmazzo, G. R., Honda, N. K., Prates, C. B., Vieira, M. do C., Coelho, R. G., Antimicrobial activity of the extracts and fractions of hexanic fruits of Campomanesia species (Myrtaceae), Journal of Medicinal Food 13 (5) (2010) 1273-1276. https://doi.org/10.1089/jmf.2009.0047.

[19] Cardoso, C. A. L., Salvador, M. J., Carvalho, J. E., Coelho, R. G., Avaliação das atividades antiproliferativa e antioxidante em frutos de Campomanesia pubescens/Evaluation of antioxidant and antiproliferative activities in fruits of Campomanesia pubescens, Revista Instituto Adolfo Lutz $72 \quad$ (4) 309-315. https://pesquisa.bvsalud.org/portal/resource/pt/lil742458 .

[20] Catelan, T. B. S., Radai, J. A. S., Leitão, M. M., Branquinho, L. S., Vasconcelos, P. C. de P., HerediaVieira, S. C., Kassuya, C. A. L., Cardoso, C. A. L., Evaluation of the toxicity and anti-inflammatory activities of the infusion of leaves of Campomanesia guazumifolia (Cambess.) O. Berg, Journal of

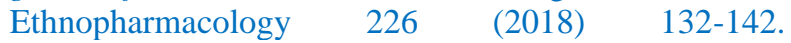
https://doi.org/10.1016/j.jep.2018.08.015.

[21] Nesello, L. Â. N., Campos, A., Wagner, T., Feliciano, A. S., Buzzi, F. de C., Cechinel Filho, V., Chemical composition and antinociceptive potential of Campomanesia reitziana fruits, Journal of Medicinal $\begin{array}{lllll}\text { Food } & 19 & \text { (5) (2016) 518-520. }\end{array}$ https://doi.org/10.1089/jmf.2015.0092.

[22] Bonilla, A., Duque, C., Garzón, C., Takaishi, Y., Yamaguchi, K., Hara, N., Fujimoto, Y., Champanones, yellow pigments from the seeds of champa (Campomanesia lineatifolia), Phytochemistry. 66 (14) (2005) https://doi.org/10.1016/j.phytochem.2005.05.025.

[23] Osorio, C., Alarcon, M., Moreno, C., Bonilla, A., Barrios, J., Garzón, C., Duque, C., Characterization of odor-active volatiles in champa (Campomanesia lineatifolia R. \& P.), Journal of Agricultural and Food $\begin{array}{llll}\text { Chemistry } & 54 & \text { (2) (2006) 509-516. }\end{array}$ https://doi.org/10.1021/jf052098c.

[24] Stefanello, M. E. A., Pascoal, A. C. R. F., Salvador, M. J., Essential oils from neo-tropical Myrtaceae: chemical diversity and biological properties, Chemistry \& Biodiversity 8 (1) (2011)7394. https://doi.org/10.1002/cbdv.201000098.
[25] Pascoal, A. C. R. F., Lourenço, C. C., Sodek, L., Tamashiro, J. Y., Franchi Junior, G. C., Nowill, A. E., Stefanello, M. É. A., Salvador, M. J., Essential oil from the leaves of Campomanesia guaviroba (DC.) Kiaersk. (Myrtaceae): chemical composition, antioxidant and cytotoxic activity, Journal of Essential Oil Research 23 (5) (2011) 34-37. https://doi.org/10.1080/10412905.2011.9700479.

[26] Kumar, G., Karthik, L., Rao, K. V. B., Haemolytic activity of Indian medicinal plants toward human erythrocytes: an in vitro study, Elixir International Journal Applied Botany 40 (2011) 5534-5537. https://www.elixirpublishers.com/articles/1350647393 _40\%20(2011)\%205534-5537.pdf.

[27] Vieira, R. F., Costa, T. da S. A., Silva, D. B. da, Ferreira, F. R., Sano, S. M., Frutas nativas da região Centro-Oeste, Embrapa Recursos Genéticos e Biotecnologia, Brasília, 2006. http://www.agabrasil.org.br/_Dinamicos/livro_frutas_n ativas_Embrapa.pdf.

[28] Carvalho, P. E. R., Espécies arbóreas brasileiras. Coleção Espécies Arbóreas Brasileiras, Embrapa informações Tecnológica, Brasília, 2006, v2. https://livimagens.sct.embrapa.br/amostras/00079500.p df.

[29] Alice, C. B., Plantas medicinais de uso popular: atlas farmacognóstico, Canoas, 1995, 205 p.

[30] Guerrero, F. M. G., Zimmerman, L. R., Cardoso, E. V., Lima, C. A. C. de, Perdomo, R. T., Alva, R., Carollo, C. A., Guerrero, A. T., Investigação sobre a toxicidade crônica de folhas de guavira (Campomanesia pubescens) em ratos machos, Revista $\begin{array}{lllll}\text { Fitos } & 5 & \text { (2) 64-72. }\end{array}$ https://www.arca.fiocruz.br/handle/icict/19179.

[31] Araújo, M. C. de P. M., Barcellos, N. M. S., Vieira, P. M. de A., Gouveia, T. M., Guerra, M. O., Peters, V. M., Saúde-Guimarães, D. A., Acute and sub chronic toxicity study of aqueous extract from the leaves and branches of Campomanesia velutina (Cambess) O. Berg, Journal of Ethnopharmacology $201 \quad$ (2017) 17-25. https://doi.org/10.1016/j.jep.2017.02.043.

[32] Alam, M. N., Bristi, N. J., Rafiquzzaman, M., Review on in vivo and in vitro methods evaluation of antioxidant activity, Saudi Pharmaceutical Journal 21 (2) (2013) 143-152. https://doi.org/10.1016/j.jsps.2012.05.002.

[33] Pavan, F. R., Leite, C. Q. F., Coelho, R. G., Coutinho, I. D., Honda, N. K., Cardoso, C. A. L., Vilegas, W., Leite, S. R. de A., Sato, D. N., Evaluation 
of anti Mycobacterium tuberculosis activity of Campomanesia adamantium (Myrtaceae), Química $\begin{array}{lllll}\text { Nova } & 32 & \text { (5) (2009) 1222-1226. }\end{array}$ https://doi.org/10.1590/S0100-40422009000500026.

[34] Brandelli, C. L. C., Vieira, P. de B., Macedo, A. J., Tasca, T., Remarkable Anti-Trichomonas vaginalis activity of plants traditionally used by the MbyáGuarani indigenous group in Brazil, BioMed Research $\begin{array}{lllll}\text { International } & 2013 \quad \text { (826370) } & \text { (2013) }\end{array}$ https://doi.org/10.1155/2013/826370.

[35] Sandhar, H. K., Kumar, B., Prasher, S., Tiwari, P., Salhan, M., Sharma, P., A review of phytochemistry and pharmacology of flavonoids, Internationale Pharmaceutica Sciencia 1 (1) (2011) 25-41.

[36] Moura-Costa, G. F., Nocchi, S. R., Ceole, L. F., Mello, J. C. P. de, Nakamura, C. V., Dias Filho, B. P., Temponi, L. G., Ueda-Nakamura, T., Antimicrobial activity of plants used as medicinals on an indigenous reserve in Rio das Cobras, Paraná, Brazil, Journal of $\begin{array}{lllll}\text { Ethnopharmacology } & 143 & \text { (2) (2012) 631-638. }\end{array}$ https://doi.org/10.1016/j.jep.2012.07.016.

[37] Markman, B. E. O., Bacchi, E. M., Kato, E. T. M., Antiulcerogenic effects of Campomanesia xanthocarpa, Journal of Ethnopharmacology 94 (1) (2004)

https://doi.org/10.1016/j.jep.2004.04.025.

[38] Silva, É. R. S. da, Salmazzo, G. R., Arrigo, J. da S., Oliveira, R. J., Kassuya, C. A. L., Cardoso, C. A. L., Anti-inflammatory evaluation and toxicological analysis of Campomanesia xanthocarpa Berg, Inflammation $39 \quad$ (4) (2016) 1462-1468. https://doi.org/10.1007/s10753-016-0378-3.

[39] Souza-Moreira, T. M., Salvagnini, L. E., Santos, E., Silva, V. Y. A., Moreira, R. R. D., Salgado, H. R. N., Pietro, R. C. L. R., Antidiarrheal activity of Campomanesia xanthocarpa fruit, Journal of Medicinal Food $14 \quad$ (5) (2011) 528-531. https://doi.org/10.1089/jmf.2009.0278.

[40] Pereira, M. C., Steffens, R. S., Jablonski, A., Hertz, P. F., Rios, A. de O., Vizzotto, M., Flôres, S. H., Characterization and antioxidant potential of brazilian fruits from the myrtaceae family, Journal of Agricultural and Food Chemistry 60 (12) (2012) 30613067. https://doi.org/10.1021/jf205263f.

[41] Klafke, J. Z., Silva, M. A. da, Rossato, M. F., Trevisan, G., Walker, C. I. B., Leal, C. A. M., Borges, D. O., Schetinger, M. R. C., Moresco, R. N., Duarte, M. M. M. F., Santos, A. R. S. dos, Viecili, P. R. N., Ferreira, J., Antiplatelet, Antithrombotic, and Fibrinolytic Activities of Campomanesia xanthocarpa,
Evidence-Based Complementary and Alternative $\begin{array}{llll}\text { Medicine } & 2012 \quad \text { (954748) (2012) 1-8. }\end{array}$ https://doi.org/10.1155/2012/954748.

[42] Otero, J. S., Hirsch, G. E., Klafke, J. Z., Porto, F. G., Almeida, A. S. de, Nascimento, S., Schmidt, A., Silva, B. da, Pereira, R. L. D., Jaskulski, M., Parisi, M. M., Guarda, N. dos S., Moresco, R. N., Aita, C. A. M., Viecili, P. R. N., Inhibitory effect of Campomanesia xanthocarpa in platelet aggregation: Comparison and synergism with acetylsalicylic acid, Thrombosis $\begin{array}{llll}\text { Research } & 154 & \text { (2017) } & \text { 42-49. }\end{array}$ https://doi.org/10.1016/j.thromres.2017.03.020.

[43] Lima, N. V. de, Arakaki, D. G., Tschinkel, P. F. S., Silva, A. F. da, Guimarães, R. de C. A., Hiane, P. A., Nascimento, V. A. do, Investigation of Campomanesia Components: A Fruit of Brazilian Cerrado, In: Active Ingredients from Aromatic and Medicinal Plants, El-Shemy, H. A., ed., InTech: Houston, United States of America, 2017, Ch. 5. https://doi.org/10.5772/66220.

[44] Lescano, C. H., Oliveira, I. P. de, Zaminelli, T., Baldivia, D. da S., Silva, L. R. da, Napolitano, M., Silvério, C. B. M., Lincopan, N., Sanjinez-Argandoña, E. J., Campomanesia adamantium Peel extract in antidiarrheal activity: the ability of inhibition of heatstable enterotoxin by polyphenols, Plos One 11 (10) (2016) $1-15$. https://doi.org/10.1371/journal.pone.0165208.

[45] Pascoal, A. C. R. F., Ehrenfried, C. A., Lopez, B. G.-C., Araujo, T. M. de, Pascoal, V. D. B., Gilioli, R., Anhê, G. F., Ruiz, A. L. T. G., Carvalho, J. E. de, Stefanello, M. É. A., Salvador, M. J., Antiproliferative activity and induction of apoptosis in PC-3 cells by the chalcone cardamonin from Campomanesia adamantium (Myrtaceae) in a bioactivity-guided study, Molecules $\quad 19 \quad$ (2) (2014) 1843-1855. https://doi.org/10.3390/molecules19021843.

[46] Silva M. C. B. L. e, Bogo, D., Alexandrino, C. A. F., Perdomo, R. T., Figueiredo, P. de O., Prado, P. R. do, Garcez, F. R., Kadri, M. C. T., Ximenes, T. V. N., Guimarães, R. de C. A., Sarmento, U. C., Macedo, M. R. L., Antiproliferative Activity of Extracts of Campomanesia adamantium (Cambess.) O. Berg and Isolated Compound Dimethylchalcone Against B16F10 Murine Melanoma, Journal of Medicinal Food 21 (10) (2018) 1-11. https://doi.org/10.1089/jmf.2018.0001.

[47] Ferreira, L. C., Grabe-Guimarês, A., Paula, C. A. de, Michel, M. C. P., Guimarães, R. G., Rezende, S. A., Souza Filho, J. D. de, Saúde-Guimarães, D. A., Anti-inflammatory and antinociceptive activities of Campomanesia adamantium, Journal of 


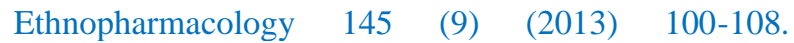
https://doi.org/10.1016/j.jep.2012.10.037.

[48] Cabral, C. de O., Campos, A., Silva, L. M. da, Boeing, T., Andrade, S. F. de, Cechinel Filho, V., Nesello, L. Â. N., Gastroprotective potential of methanolic extract and dimethyl cardamonin from Campomanesia reitziana fruits in mice, NaunynSchmiedeberg's Archives of Pharmacology 390 (6) (2017) 661-666. https://doi.org/10.1007/s00210-0171369-0.

[49] Madalosso, R. C., Oliveira, G. C., Martins, M. T., Vieira, A. E. D., Barbosa, J., Caliari, M. V., Castilho, R. O., Tagliati, C. A., Campomanesia lineatifolia Ruiz \& Pav. as a gastroprotective agente, Journal of $\begin{array}{llll}\text { Ethnopharmacology } & 139 & \text { (2012) } & \text { 772-779. }\end{array}$ https://doi.org/10.1016/j.jep.2011.12.014.

[50] Ekor, M., The growing use of herbal medicines: issues relating to adverse reactions and challenges in monitoring safety, Frontiers in Pharmacology 4 (177) (2014) 1-10. https://doi.org/10.3389/fphar.2013.00177.

[51] França, I. S. X. de, Souza, J. A. de, Baptista, R. S., Britto, V. R. de S., Medicina popular: benefícios e malefícios das plantas medicinais, Revista Brasileira de

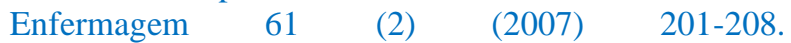
https://doi.org/10.1590/S0034-71672008000200009.

[52] Silveira, P. F. da, Bandeira, M. A. M., Arrais, P. S. D., Farmacovigilância e reações adversas às plantas medicinais e fitoterápicos: Uma realidade, Revista Brasileira de Farmacognosia 18 (4) (2008) 618-626. https://doi.org/10.1590/S0102-695X2008000400021.

[53] Raynor, D. K., Dickinson, R., Knapp, P., Long, A. F., Nicolson, D. J., Buyer beware? Does the information provided with herbal products available over the counter enable safe use? BMC Medicine 9 (94) (2011) 1-8. https://doi.org/10.1186/1741-7015-994.

[54] Villas Boas, G. R., Santos, A. C. dos, Souza, R. I. C., Araújo, F. H. S. de, Traesel, G. K., Marcelino, J. M., Silveira, A. P. S. da, Farinelli, B. C. F., Cardoso, C. A. L., Lacerda, R. B. de, Oesterreich, S. A., Preclinical safety evaluation of the ethanolic extract from guavira fruits (Campomanesia pubescens (D.C.) O. BERG) in experimental models of acute and short-term toxicity in rats, Food and Chemical Toxicology 118 (2018) 1-12. https://doi.org/10.1016/j.fct.2018.04.063.

[55] Pastori, T., Flores, F. C., Boligon, A. A., Athayde, M. L., Silva, C. de B. da, Canto-Dorow, T. S. do, Tedesco, S. B., Genotoxic effects of Campomanesia xanthocarpa extracts on Allium cepa vegetal system,
Pharmaceutical Biology. 51 (10) (2013) 1249-1255. https://doi.org/10.3109/13880209.2013.786097.

[56] Souza, J. C. de, Piccinelli, A. C., Aquino, D. F. S., Souza, V. V. de, Schmitz, W. O., Traesel, G. K., Cardoso, C. A. L., Kassuya, C. A. L., Arena, A. C., Toxicological analysis and antihyperalgesic, antidepressant, and anti-inflammatory effects of Campomanesia adamantium fruit barks, Nutritional Neuroscience: An International Journal on Nutrition, Diet and Nervous System 20 (1) (2017) 23-31. https://doi.org/10.1179/1476830514Y.0000000145.

[57] Carvalho, A. C. B., Balbino, E. E., Maciel, A., Perfeito, J. P. S., Situação do registro de medicamentos fitoterápicos no Brasil, Revista Brasileira de

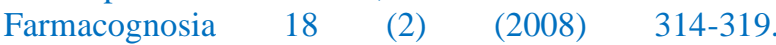
https://doi.org/10.1590/S0102-695X2008000200028.

[58] Pascoal, A. C. R. F., Ehrenfried, C. A., Eberline, M. N., Stefanello, M. É. A., Salvador, M. J., Free radical scavenging activity, determination of phenolic compounds and HPLC-DAD/ESI-MS profile of Campomanesia adamantium leaves, Natural Product Communications $6 \quad$ (7) (2011) 969-972. https://doi.org/10.1177/1934578X1100600711.

[59] Breda, C. A., Gasperini, A. M., Garcia, V. L., Monteiro, K. M., Bataglion, G. A., Eberlin, M. N., Duarte, M. C., Phytochemical analysis and antifungal activity of extracts from leaves and fruit residues of brazilian savanna plants aiming its use as safe fungicides, Natural Products and Bioprospecting 6 (4) (2016) 195-204. https://doi.org/10.1007/s13659-0160101-y.

[60] Espíndola, P. P. de T., Rocha, P. dos S. da, Carollo, C. A., Schmitz, W. O., Pereira, Z. V., Vieira, M. do C., Santos, E. L. dos, Souza, K. de P., Antioxidant and antihyperlipidemic effects of Campomanesia adamantium O. Berg Root, Oxidative Medicine and Cellular Longevity 2016 (7910340) (2016) 1-8. http://doi.org/10.1155/2016/7910340.

[61] Campos, J. F., Espíndola, P. P. de T., Torquato, H. F. V., Vital, W. D., Justo, G. Z., Silva, D. B., Carollo, C. A., Souza, K. de P., Paredes-Gamero, E. J., Santos, E. L. dos, Leaf and root extracts from Campomanesia adamantium (Myrtaceae) promote apoptotic death of leukemic cells via activation of intracellular calcium and caspase-3, Frontiers in Pharmacology 8 (466) (2017) 1-16. https://doi.org/10.3389/fphar.2017.00466.

[62] Lescano, C. H., Lima, F. F. de, Mendes-Silvério, C. B., Justo, A. F. O., Baldívia, D. da S., Vieira, C. P., Sanjinez-Argandoña, E. J., Cardoso, C. A. L., Mónica, F. Z., Oliveira, I. P. de, Effect of polyphenols from Campomanesia adamantium on platelet aggregation 
and inhibition of cyclooxygenases: molecular docking and in vitro analysis, Frontiers in Pharmacology 9 (617) (2018) 1-13. https://doi.org/10.3389/fphar.2018.00617.

[63] Villas Boas, G. R., Silveira A. P. S. da, Farinelli, B. C. F., Cardoso, C. A. L., Arce, E., Oesterreich, A. S., The ethanolic extract obtained from Campomanesia pubescens (D.C.) O.BERG fruits exerts anxiolytic and antidepressant effects on chronic mild stress model and on anxiety models in Wistar rats. Behavioral evidences, Nutritional Neuroscience: An International Journal on Nutrition, Diet and Nervous System (2018) 1-11. https://doi.org/10.1080/1028415X.2018.1466513.

[64] Catelan, T. B. S., Brum, C. C. S., Heredia-Vieira, S. C., Crispim, B. A., Grisolia, A. B., Santos, R. C. S., Cardoso, C. A. L., Cytotoxicity, Genotoxicity, Antioxidant Potential and Chemical Composition of Leaves of Campomanesia pubescens (Mart. ex DC.) O.Berg, Current Pharmaceutical Biotechnology 19 (5) (2018) 416-421. https://doi.org/10.2174/1389201019666180626102443.

[65] Villas Boas, G. R., Araújo, F. H. S. de, Marcelino, J. M., Castro, L. H. A., Silveira, A. P. S. da, Nacer, R. S., Souza, F. R. de, Cardoso, C. A. L., Lacerda, R. B. de, Guterres, Z. da D. R., Oesterreich, S. A., Preclinical safety evaluation of the ethanolic extract from Campomanesia pubescens (Mart. ex DC.) O. BERG (guavira) fruits: analysis of genotoxicity and clastogenic effects, Food \& Function 9 (7) (2018) 3707-3717. https://doi.org/10.1039/c8fo01017j.

[66] Biavatti, M. W., Farias, C., Curtius, F., Brasil, L. M., Hort, S., Schuster, L., Leite, S. N., Prado, S. R. T., Preliminary studies on Campomanesia xanthocarpa (Berg.) and Cuphea carthagenensis (Jacq.) J.F. Macbr. aqueous extract: weight control and biochemical parameters, Journal of Ethnopharmacology 93 (2-3) (2004) 385-389. https://doi.org/10.1016/j.jep.2004.04.015.

[67] Viecili, P. R. N., Borges, D. O., Kirsten, K., Malheiros, J., Viecili, E., Melo, R. D., Trevisan, G., Silva, M. A. da, Bochi, G. V., Moresco, R. N., Klafke, J. Z., Effects of Campomanesia xanthocarpa on inflammatory processes, oxidative stress, endothelial dysfunction and lipid biomarkers in hypercholesterolemic individuals, Atherosclerosis 234 (1) (2014) 85-92. https://doi.org/10.1016/j.atherosclerosis.2014.02.010.

[68] Brandelli, C. L., Ribeiro, V. B., Zimmer, K. R., Barth, A. L., Tasca, T., Macedo, A. J., Medicinal Plants Used by a Mbyá-Guarani Tribe Against Infections: Activity on KPC-Producing Isolates and Biofilm-Forming Bacteria, Natural Product
Communications $10 \quad$ (11) (2015) 1847-1852. https://doi.org/10.1177/1934578X1501001114.

[69] Schmidt, H. de O., Rockett, F. C., Pagno, C. H., Possa, J., Assis, R. Q., Oliveira, V. R. de, Silva, V. L. da, Flôres, S. H., Rios, A. de O., Vitamin and bioactive compound diversity of seven fruit species from south Brazil, Journal of the Science of Food and Agriculture $99 \quad$ (7) (2019) 3307-3317. https://doi.org/10.1002/jsfa.9544.

[70] Sousa, J. A. de, Prado, L. D. S., Alderete, B. L., Boaretto, F. B. M., Allgayer, M. C., Miguel, F. M., Sousa, J. T. de, Marroni, N. P., Lemes, M. L. B., Corrêa, D. S., Ferraz, A. B. F., Picada, J. N., Toxicological aspects of Campomanesia xanthocarpa Berg. associated with its phytochemical profile, Journal of Toxicology and Environmental Health, Part A 82 (1) (2019) https://doi.org/10.1080/15287394.2018.1562392. 